In this issue:

ACRL Remains Largest Division

ACRL Nominating Committees 1976/77 Elections

ACRL Announces Faculty Status Publication

Videocassettes Available

Inside Washington

Letters

Access Policy Guidelines

News From the Field

People

Classified Advertising

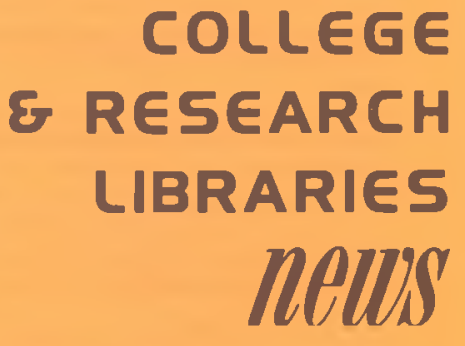

NO. 10 NOVEMBER 1975

\title{
ACRL Remains Largest Division
}

The Association of College and Research Libraries has maintained its position as the largest division of the American Library Association. According to final membership statistics released September 30, 1975, ACRL has 9,390 members, 7,131 of these being personal members and 2,259 being organizational members.

The American Association of School Librarians is the second largest division with 7,384 members. The Resources and Technical Services Division, 6,534 members, and the Refer- ence and Adult Services Division, 6,268 members, ranked third and fourth among the thirteen divisions. During 1975 ACRL launched a membership promotion campaign which resulted in 1,326 new members joining ACRL.

Membership in ACRL costs $\$ 15.00$ in addition to the $\$ 35.00$ membership fee for the ALA. Materials describing ACRL, its program, and perquisites of membership are available from the ACRL Office, 50 E. Huron St., Chicago, IL 60611 .

\section{ACRL Nominating Committees 1976/77 Elections}

The ACRL Committee on Appointments and Nominations and the ACRL section nominating committees are seeking candidates for nomination for election to office and for recommendation for appointment to committees. Persons interested in being considered for nomination or appointment or interested in making recommendations should contact a member of the appropriate committee before the Midwinter Meeting which will be held in Chicago January 18-24, 1976.

\section{ACRL Committee on Appointments and Nominations}

Chairman, H. Joanne Harrar, Director of Libraries, McKeldin Library, University of Maryland, College Park, MD 20742; members: chairmen of section nominating committees.
Agriculture and Biological Sciences Section

Nominating Committee

To be appointed.

\section{Anthropology Section Nominating Committee}

Chairman, David L. Perkins, Head Bibliographer, California State University Northridge, 18111 Nordhoff St., Northridge, CA 91324; members: Polly S. Grimshaw, Librarian for Anthropology, Sociology, and Folklore, Indiana University, Bloomington, IN 47401; Dorothy A. Koenig, Anthropology Librarian, University of California, Berkeley, CA 94720.

\section{Art Section Nominating Committee}

Chairman, James R. Burch, Assistant Head, Environmental Design Library, University of 
California, Berkeley, CA 94720; members: David J. Patten, Editor Art Index, H. W. Wilson Co., 950 University Ave., Bronx, NY 10452; Ruth E. Schoneman, Architectural Archivist, Art Institute of Chicago Library, Chicago, IL 60603.

Asian and African Section Nominating Committee

To be appointed.

College Library Section

Nominating Committee

To be appointed.

Community and Junior College Libraries Section Nominating Committee

Chairman, Margaret A. Wainer, Director of the Library, Carl Sandburg College, Galesburg, IL 61401; members: Glenn R. Dallman, Director of Library Services, St. Petersburg Junior College, Clearwater Campus, Clearwater, FL 33515; Iole L. Matteucig, Director of Library Services, City College of San Francisco, San Francisco, CA 94116.

Education and Behavioral Sciences Section Nominating Committee

Chairman, Toyo S. Kawakami, Assistant Head, Education Library, Ohio State Univer-

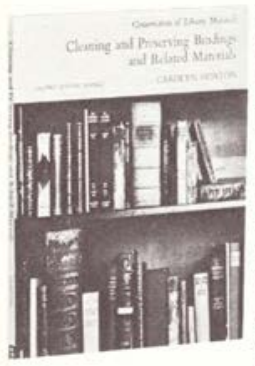

Cleaning and Preserving Bindings and Related Materials

(2d edition, revised)

\section{Carolyn Horton}

A practical guide to cleaning and conserving paper. cloth, and leather bindings. It tells how to make minor repairs to torn leaves, maps, and disintegrating bindings. Discusses procedures for attaching book plates, enclosures, and loose illustrations. and ways to avoid the dangers of migratory acids in materials. Includes information about supplies and equipment used in conservation work. Over 30 drawings clarify points in the text. Useful to librarians, conservators, and private collectors. This is the first volume in LTP's series on the conservation of library materials. LTP Publication No. $16108 \mathrm{p}$. Paper LC 76-95200 ISBN 0-8389-3008-5 \$5.00

Order Department

AMERICAN LIBRARY ASSOCIATION

50 East Huron St., Chicago, IL 60611 sity, Columbus, OH 43210; members: Ruth Murray, Education/Psychology Bibliographer, Regenstein Library, University of Chicago, Chicago, IL 60637; Charles R. Rushton, Director, Instructional Resource Center, Eastern New Mexico University, Portales, NM 88130

Law and Political Science Section

Nominating Committee

To be appointed.

Rare Books and Manuscripts Section Nominating Committee

Chairman, Mihai H. Handrea, Librarian, Carl H. Pforzheimer Library, 41 East 42nd St., New York, NY 10017; members: Julius P. Barclay, Librarian, Rare Book Department, Alderman Library, University of Virginia, Charlottesville, VA 22901; Clive E. Driver, Director, Philip H. and A. S. W. Rosenbach Foundation Museum and Library, Philadelphia, PA 19103.

Slavic and East European Section

Nominating Committee

To be appointed.

University Libraries Section

Nominating Committee

Chairman, Elizabeth Salzer, J. Henry Meyer Library, Stanford University, Stanford, CA 94305; members: Charles Churchwell, Brown University Library, Providence, RI 02912; Irene B. Hoadley, Texas A \& M University Library, College Station, TX 77843.

an

News ifems for inclusion in C\&RL News should be sent to Mary Frances Collins, Assistant Director of Libraries for Technical Services, University Library ULB-35A, State University of New York at Albany, 1400 Washington Are. Albany, NY 12222. Adrertising (including classified ads) should be sent to Leona Swiech, Advertising Office, American Library Association, 50 E. Huron Si., Chicago, IL 60611 . Production and circulation matters are han. dled by ALA Central Production Unit, at the above address.

News editor: Mary Frances Collins, Assistant Director of Libraries for Technical Services, State University of New York at Albany, Albany. As. sociate News editor: Anne Dowling, Assistant Li. brarian, Acquisitions Department, Library. State University of New York at Albany. Editor: Rich. ard D. Johnson, Milne Library, State University College, Oneonta, New York 13820. Piesident, ACRL: Louise Giles. Executive Secretary, ACRL: Beverly P. Lynch.

College Research Libraries is published by the Association of College and Research Libraries, division of the American Library Association, 17 times yearly $\rightarrow$ bimonthly journal issues and II monthly (combining July-August) News issues-at 1201.05 Bluff St., Fulton, MO 65251. Subscription. $\$ 15.00$ a year, or to members of the division, $\$ 7.50$, included in dues. Second-class postage paid at Fulton, Missouri 65251 .

(C) American Library Association 1975. All material in this journal subject to copyright by the American Library Association may be photocopied for the noncommercial purpose of scientific or educa. fional advancement. 